\title{
Osteoporotik Yaşlılarda Denge Bozukluğu
}

\section{Balance Disorders in the Osteoporotic Elderly}

Şule Şahin Onat, Zuhal Özişler, Kurtuluş Köklü

Ankara Fizik Tedavi Eğitim ve Araştırma Hastanesi, Ankara, Türkiye

\section{Özet}

Ilerleyen yaşla birlikte insan vücudunun "yaşlanma" sürecine girmesiyle hücreler ve organlarda geri dönüşü olmayan ve bireyler arasında farklılık gösteren değişiklikler meydana gelmektedir. Osteoporotik yaşlılarda kemikte ve diğer tüm organlarda meydana gelen değişimler sonucunda ortaya çıkan denge bozuklukları ve düşmelerle bireyin fonksiyonelliği, yaşam kalitesi azalmaktadır. Bu derlemedeki amacımız yaşlı osteoporotik bireylerde denge bozukluğu gelişimi ve bunun sonucu olan düşmeyi gözden geçirmektir. (Türk Osteoporoz Dergisi 2013;19: 87-9)

Anahtar kelimeler: Yaşll, osteoporoz, denge bozukluğu

\section{Summary}

With advancing age, when the human body entry "aging" process, cells and organs occur irreversible changes. How does qualitative changes in the elderly osteoporotic bone, such that changes occur in other organs. As a result, with balance disorders and fall down arisen in elderly osteoporotic individuals, the quality of life decreases. Our aim in this presentation is to review the occurance of the balance disorder on elderly osteoporotic individuals and fall down conclusion. (Turkish Journal of Osteoporosis 2013;19: 87-9)

Key words: Elderly, osteoporosis, balance disorder

\section{Giriş}

Yaşlılık; morfolojik, fizyolojik ve patolojik değişlikliklerin olumsuz yönde ilerlediği, çeşitli hastalıkların birleştiği fiziksel ve ruhsal yeteneklerin gerilediği bir yetmezlik olayıdır (1). Ilerleyen yaşla birlikte insan vücudunda "yaşlanma" sürecine girilmesiyle hücreler ve organlarda geri dönüşü olmayan ve bireyler arasında farklılık gösteren değişiklikler meydana gelmektedir. Osteoporotik yaşlılarda kemikte ve diğer tüm organlarda niteliksel değişiklikler oluşmaktadır. Bunların sonucunda meydana gelen denge bozuklukları ve düşmelerle bireyin fonksiyonelliği, yaşam kalitesi azalmaktadır.

Denge, istirahatte ve aktivite sırasında, yer çekimi merkezini destek yüzeyi üzerinde tutabilmek için gerçekleştirilen postüral uyumdur. Yaşlılarda postüral kontrolde bozulma sonucunda hem statik hem de dinamik denge bozulmaktadır (1). Normal postüral kontrol ve dengenin sağlanmasında etkili olan üç sistem; vestibüler sistem, görme sistemi ve somatosensör sistemdir (1). Normal koşullarda bu üç sistem etkileşir ve vücudun uzayda lokalizasyonu hakkında bilginin sağlanmasıyla postüral kontrolü gerçekleştirir (Şekil 1). Yaşlanmayla bu sistemlerin fonksiyonundaki ve organizasyondaki bozulmalar sonucu denge bozuklukları ortaya çıkmaktadır.

Vestibüler sistemde semisirküler kanallar, sakkül ve utrikulun makulasındaki tüy hücrelerinde dejeneratif değişiklikler, ampullada tüy hücre kaybı oluşmaktadır. Yetmiş yaş ve üzerindeki bireylerde semisirküler kanallarda tüy hücre sayısında \%40 oranında, maküler tüy hücre sayısında ultriküler makulada \%21, sakküler makulada \%24 oranında azalma bulunmuştur (1). Kapillerlerin ve küçük arteryiollerin duvar kalınlığında azalma meydana gelmektedir. Yaşlanma sonucunda sinir liflerinin sayısında ve miyelinli liflerin kalınlığında da azalma görülmektedir. Görme sisteminde yaşlanma sonucunda görme alanı daralması, gözün odaklama yeteneğinde bozulma, karanlığa-ışığa hassasiyette ve renk hassasiyetinde azalma meydana gelmektedir. Bunun sonucunda postüral kontrolü sağlamada önemli olan çevre ve derinlik algısı bozulmaktadır (2). Yaşlanmayla birlikte sinir iletim hızında ve alt ekstremitelerin periferal duysal reseptörlerinin sayısında azalma, duyu ve motor sinirlerin latans periyodunda ise artma görülmektedir. Yaşla birlikte duyu reseptörlerinin bilgiyi yetersiz algılması veya bu mesajların iletimini etkileyen bozukluklar sonucunda hareket düzenleme yeteneği bozulmaktadır (3). 


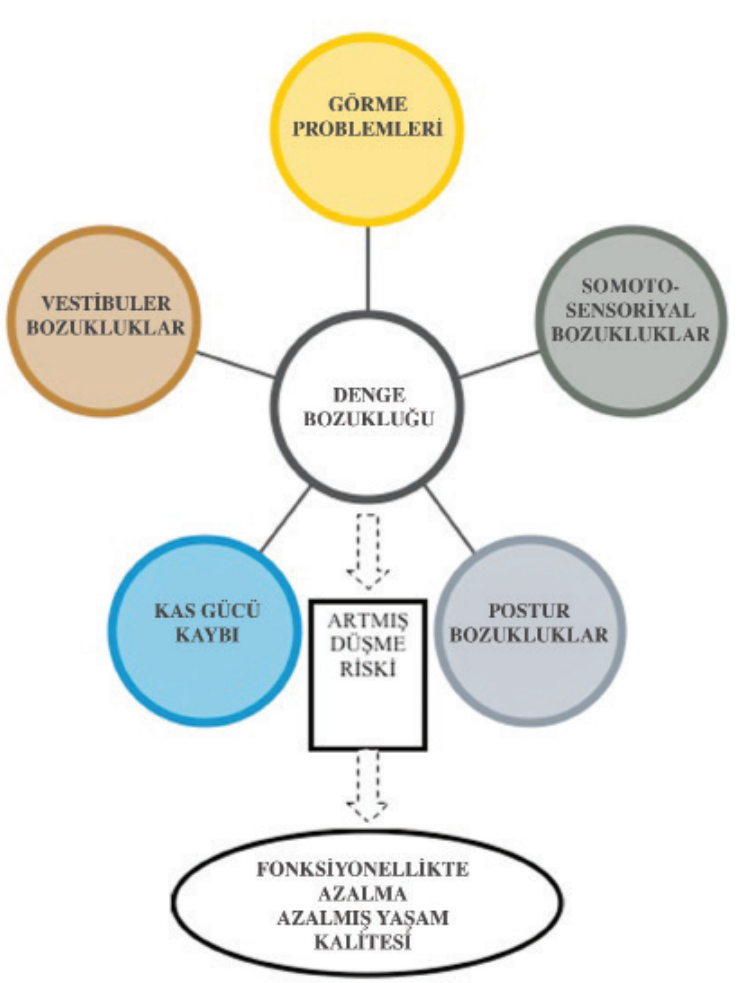

Şekil 1. Denge bozukluğu ve düşme riskinin artmasında etkili olan faktörler

Denge sistemine katkıda bulunan bir diğer sistem de kas-iskelet sistemidir. Yaşlanmayla birlikte kas lif sayısında azalma (lif kaybı) ve kalan liflerin kesit alanlarında azalma (lif atrofisi) kas zayıflığına neden olmaktadır (4). Kas zayıflığının artması denge bozukluğuna etki eden önemli bir faktördür (5). Osteoporozda kas kuvvetinin azalması neden midir sonuç mudur açıklağa kavuşmasa da kas kuvvetleri ve kemik mineral yoğunluğu (KMY) arasındaki ilişki çalışmalarda gösterilmiştir (6). Özellikle gövde kas kuvvetleri, hastalarda günlük yaşam sırasında denge yeteneğinin sağlanması ve korunmasında önemlidir. Postural stabilite için gövde kas kuvvetlerinin yeterli olması gereklidir. Yaşlanmayla sedanter yaşama bağlı immobilizasyon da hem kas kuvvetlerinde hem de KMY'de azalma için bir risk faktörüdür (7). Yine yaşlllarda antagonistik kaslarda kasılmaların daha fazla olması kas aktivasyonuna başlamada gecikmeye yol açmaktadır Kas kullanımındaki bu değişiklikler, dik duruşu devam ettirmeyi zorlaştırarak dengedeki bozulmayı daha da arttırmaktadır (8). Özellikle alt ekstremitede diz ekstansör ve ayak bileği plantar fleksör kas gruplarının kuvvetlerinde azalma yaşlılarda düşmeler için bir risk faktörüdür (9). Bir çalışmada 20 osteoporoz ve 30 sağlıklı olgunun 60-180$300^{\circ} / \mathrm{sn}$ açısal hızlarda quadriceps-hamstring kas güçlerinin izokinetik sistemle ölçümlerinin yapıldığı bir çalışmada, sağlıklı kadınlara göre osteoporotik kadınlarda postural dengenin önemli derecede bozulduğu ve dengeyi etkileyen en önemli faktörün quadriceps kas gücü olduğu gösterilmiştir (10). Başka bir çalışmada da osteoporozu olan 65 yaş ve üzeri kadınlarda yüksek hızda değerlendirilen izokinetik konsantrik gövde ekstansor kuvvetlerinin daha düşük olduğu bulunmuştur (11).
Hem yaşlılık hem de osteoporozda fleksiyon postürü hakimdir. Boy kısalmış, baş öne eğik, omuzlar düşük, dorsal kifoz artmış, üst ve alt ekstremiteler ile gövde hafif fleksiyondadır. Postüral bozukluklar ayakta durma dengesini olumsuz etkilemekte ve ayakta durmayı sağlamak için postüral bozuklukları saptama ve uygun postüral yanıtları oluşturma yeteneği gerekmektedir (1). Bu yetenek yaşlanma sonucunda bozulmakta ve denge bozukluğu ile düşme riskinin artmasına yol açmaktadır.

Yaşlı osteoporotik bireylerde ayakta durma yeteneğinin azalması, postüral salınımın artması, dinamik dengenin, yürüme hızının, mobilitenin, diz, kalça ve ayak bileği kuvvetinin azalmasından dolayı düşme riski artmaktadır (12). Tinetti ve ark. ları düşme sıklığının ilerleyen yaşla arttığını ama sadece \%44 oranında çevresel faktörlere bağlı olduğunu ve geriye kalan büyük bölümünü oluşturan çevresel olmayan faktörlerden en önemlisinin postüral denge ve alt ekstremite kas kuvvetindeki azalmalar olduğunu ifade etmişlerdir (13). Bir çalışmada düşme varlığı olan grupta Berg Denge Skalası skorlarının düşme olmayan gruba göre anlamlı olarak daha düşük olduğu, yaşam kalitesi skorlarının da düşmeyen grupta daha yüksek olduğu gösterilmiştir (14). Yani postüral dengenin kontrolü yaşla birlikte azalmakta ve düşme sıklığının artmasına neden olmaktadır. Yaşlılarda düşmeler mortaliteye neden olan faktörlerin başında gelmektedir. Her yıl toplumda yaşayan 65 yaş üzeri yetişkinlerin \%30-40'ı düşmekte, 80 yaş ve üzeri kişilerde bu oran \%50'ye kadar yükselmektedir $(15,16)$. Tüm düşmelerin yaklaşık \%10'u major travmayla sonuçlanmakta, hastaların \%10-20'si acil servise başvurmak zorunda kalmaktadır (17). Düşme sonucu kırık oranı ise \%5 civarındadır (18). Ama düşme, kırık olmasa bile fiziksel fonksiyon kaybı, bağımsız yaşamın kaybı, bakım evine yatış ve mortaliteye de neden olabilmektedir $(19,20)$. Düşme sonrası kişinin kendine güveninde azalma, ciddi yaralanma olmamasına rağmen fonksiyonların kısıtlanmasını açıklayabilir (21).

Özetle düşme, kişinin sosyal yaşama katılımı ve kendi kendine bakabilme yeteneğini azaltan en önemli olaylardandır (22). Bundan dolayı yukarda mekanizmaları anlatılan denge bozukluğunun ve düşme riskinin azaltılması osteoporotik yaşlılarda mortaliteyi ve morbiditeyi azaltmaya, olguların yaşam kalitesinin yükseltilmesine neden olacaktır.

\section{Kaynaklar}

1. Calder JH. Aging and the balance control systems. In: Weinstein EB, editor. Geriatric Audiology. $4^{\text {th }}$ ed. New York, Thieme; 2000. p. 141-67.

2. Black A, Wood J. Vision and falls. Clin Exp Optom 2005;88:21222.

3. Khristinsdottir EK, Fransson PA, Magnusson M. Changes in postural control in healthy elderly subjects are related to vibration sensation, vision and vestibular asymmetry. Acta Otolaryngol 2001;121:700-6.

4. Dikmenoğlu N. Değişik sistemlerde yaşlanma olgusu. In: Beyazova M, Kutsal YG, editörler. Fiziksel Tıp ve Rehabilitasyon. Ankara: Güneş Kitabevi; 2000. s. 1305-40.

5. Woollacott MH, Shumway-Cook A. Changes in posture control across the life span- a systems approach. Phys Ther 1990;70:799807.

6. Iki M, Saito Y, Kajita E, Nishino H, Kusaka Y. Trunk muscle strength is a strong predictor of bone loss in postmenopausal women. Clin Orthop Relat Res 2006;443:66-72. 
7. Sinaki M, Brey RH, Hughes CA, Larson DR, Kaufman KR. Balance disorder and increased risk of falls in osteoporosis and kyphosis: significance of kyphotic posture and muscle strength. Osteoporos Int 2005;16:1004-10.

8. Myers AH, Baker SP, Van Natta ML, Abbey H, Robinson EG. Risk factors associated with falls and injuries among elderly institutionalized persons. Am J Epidemiol 1991;133:1179-90.

9. Lord SR, Catherine MH. Falls in older people: Risk factors and strategies for prevention. Cambridge University Press, 2000:40-54

10. Ünlüsoy $D$, Aydoğ $E$, Tuncay R, Eryüksel R, Ünlüsoy $i$, Çakcı $A$. Postural balance in women with osteoporosis and effective factors. Turkish Journal of Osteoporosis 2011;17:37-43.

11. Taşkıran Ö, Taş N, Meray J. Altmış beş yaş ve üzeri kadınlarda izokinetik gövde fleksör ve ekstansör kas kuvvetleri ile osteoporoz ilişkisi. Türk Fiz Tıp Rehab Derg 2012;58:272-6.

12. Rogers ME, Rogers NL, Takeshima N, Islam MM. Methods to assess and improve the physical parameters associated with fall risk in older adults. Prev Med 2003;36:255-64.

13. Tinetti ME, Speechley M, Ginter SF. Risk factors for falls among elderly persons living in the community. N Engl J Med 1988;319:1701-7.

14. Uz Tunçay S, Özdinçler AR, Erdinçler SD. Geriatrik hastalarda düşme risk faktörlerinin günlük yaşam aktiviteleri ve yaşam kalitesine etkisi. Turkish Journal of Geriatrics 2011;14:245-52.

15. Gillespie LD, Robertson MC, Gillespie WJ, Lamb SE, Gates S, Cumming RG, et al. Interventions for preventing falls in older people living in the community. Cochrane Database Syst Rev 2009;2:CD007146.
16. Cameron ID, Murray GR, Gillespie LD, Robertson MC, Hill KD, Cumming RG, et al. Interventions for preventing falls in older people in nursing care facilities and hospitals. Cochrane Database Syst Rev 2010;1:CD005465.

17. Kannus $P$, Sievanen $H$, Palvanen $M$, Jarvinen $T$, Parkkari J. Prevention of falls and consequent injuries in elderly people. Lancet 2005;366:1885-93.

18. Salva A, Bolibar I, Pera G, Arias C. Incidence and consequences of falls among Iderly people living in the community. Med Cli (Barc) 2004;122:172-6.

19. Stel VS, Smit JH, Pluijm SM, Lips P. Consequences of falling in older men and women and risk factors for health service use and functional decline. Age Ageing 2004;33:58-65.

20. Zijlstra GA, van Haastregt JC, van Eijk JT, van Rossum E, Stalenhoef PA, Kempen GI. Prevalence and correlates of fear of falling, and associated avoidance of activity in the general population of community-living older people. Age Ageing 2007;36:304-9.

21. Delbaere K, Crombez G, Vanderstraeten G, Willems T, Cambier D. Fear- related avoidance of activities, falls and physical frailty. A prospective community-based cohort study. Age Ageing 2004;33:368-7.

22. Gill TM, Desai MM, Gahbauser EA, Holford TR Williams CS. Restricted activities among community living older person: Incidence, precipitants and health care utilization. Ann Intern Med 2001;135:313-21 